\title{
Tujuan Pendidikan Islam dalam Mencetak SDM Unggul
}

\author{
Mila Mahmudah \\ STAI Taruna Surabaya \\ Email milamahmudah91495@gmail.com
}

\begin{abstract}
Abstrack; Since the beginning of the development of Islamic education has stood upright on two very important basic sources namely the Al-Quran and the sunnah of the prophet in the sacred scripture contained verses of mufasshalat (detailed) and verses of mubbayyinat (which provide proof of truth) that encourage humans to study and write and to study, think about and analyze the creation of heaven and earth. Islam since its inception shows the importance of education for human life. The first verse received by the prophet Muhammad is iqro "which contains a message about the command to deceive the potential of human reason, and that is at the core of education in Islam. However, it must be recognized that Islamic education at that time did not yet have a formal and systematic form, because the role of education at the beginning of the development of Islam was still limited to efforts to spread Islamic da'wah in the form of monotheism and religious ritual practices. While the teachings of religion that must be obeyed in human life, turned into mere spectacle. All show that the progress of science and technology in the 20th century, apparently not only brought something positive to human life, but also had a negative impact. By looking at various events that identify the lack of understanding of morality above, to provide a strong foundation for humans to come, it is necessary to innovate moral cultivation in the world of education or better known as moral education. In the world of education or better known as moral education. Whereas moral education is not far from implementing Islamic education. Thus the mastery and application of science and technology needs to be developed on the basis of ethics, morality and spiritual (imtaq) in the development of facing the era of improvement of science and technology, national development should also necessitate the importance of the value of faith and piety (imtaq) towards God. So as to create superior human resources according to Islam and be able to deal with the development of the era and era of globalization.
\end{abstract}

Keywords: Islamic Education Objectives, Superior Human Resources 


\section{Pendahuluan}

Pendidikan pada dasarnya adalah usaha sadar untuk menumbuhkembangkan potensi sumber daya manusia peserta didik dengan cara mendorong, menfasilitasi kegiatan belajar. Secara detail , dalam Undang-Undang RI no. 20 tahun 2003 tentang sistem pendidikan nasional Bab 1 Pasal 1 didefiniskan sebagai usaha sadar untuk mewujudkan suasana belajar dan proses belajar agar peserta didik secara aktif mengembangkan potensi dirinya untuk memiliki kekuatan spiritual keagamaan, pengendalian diri, kepribadiannya, kecerdasan, akhlak mulia, serta ketrampilan yang diperlukan dirinya, masyarakat, bangsa dan negara. ${ }^{1}$

Pendidikan merupakan alat untuk meningkatkan kecerdasan manusia. Dengan pendidikan, manusia merajai alam dunia ini sehingga tidak jarang manusia lupa kepada jati dirinya sebagai makhluk yang lemah dan tidak berdaya di mata Allah ${ }^{2}$. Pendidikan bagi manusia telah ada dan berkembang dari zaman primitive, yang berlangsung pada zaman ketika manusia masih berada dalam ruang lingkup kehidupan yang serba sederhana. Tujuan-tujuannya pun amat terbatas pada hal-hal yang bersifat survival (bertahan hidup terhadap ancaman alam sekitar), yaitu ketrampilan membuat alat-alat untuk mencari dan memproduksi bahan-bahan kebutuhan hidup, beserta pemeliharaannya.

Peranan pendidikan dalam pengembangan kualitas sumber daya insani secara mikro, sebagai proses belajar-mengajar ; alih pengetahuan (transfer of knowlegde), alih metode (transfer of methodology) dan alih nilai ( transfer of value). Fungsi pendidikan sebagai sarana alih pengetahuan dapat ditinjau dari teori "human capital", bahwa pendidikan tidak dipandang sebagai barang konsumsi belaka tetapi juga sebagai sebuah investasi. Hasil investasi ini berupa tenaga kerja yang mempunyai kemampuan untuk menerapkan pengetahuan dan ketrampilannya dalam proses produksi dan pembangunan pada umumnya. Dalam kaitan ini proses alih pengetahuan dalam rangka pembinaan ilmu pengetahuan. Dengan ilustrasi yang serupa, proses alih pengetahuan

\footnotetext{
${ }^{1}$ Mahfud Sholahuddin, Metode Pendidikan Islam, Surabaya, Bina Ilmu 1987 hal 107

2 Drs hasan Basri, MAg Drs Beni Ahmad Saebeni, M.Si ILMU PENDIDIKAN ISLAM (JILID II) CV PUSTAKA SETIA 2010 hal 20
} 
ini juga berperan pada proses pemberdayaan dan pembinaan iman, takwa dan akhlak mulia. $^{3}$

Dalam rangka memperbaiki sistem pendidikan nasional telah ditetapkan visi misi dan strategi, pembangunan dalam pendidikan nasioanl. Visi pendidikan nasional adalah terwujudnya sistem pendidikan sebagai pranata sosial yang kuat untuk memperdayakan semua warga negara Indonesia berkembang menjadi manusia yang berkualitas dan mampu meja kajian mengenai pendidikan masih saja merupakan hal menarik dianalisis dan dirumuskan keberadaannya. Dalam dunia termasuk Indonesia, pendidikan merupakan salah satu pilar pembangunan. Ini menandakan bahwa pendidikan tidak hanya berbicara pada konteks bagaimana pendidikan mampu memperbaiki struktur pembangunan dalam negara tersebut. Pada sisi ini pendidikan berfungsi sebagai penopang tegaknya pembangunan melalui penciptaan sumber daya manusia (SDM) berkualitas. Untuk menuju tercapainya harapan diatas, ada banyak variable yang perlu diadakan perbaikan. Sebab, pendidikan Indonesia saat ini sedang dirudung banyak masalah. Di samping itu, kondisi kritis ekonomi yang melanda Indonesia, berimplikasi serius pada pendidikan.

Pelaksanaan pendidikan tidak hanya menjadi tugas pemerintah, akan tetapi menjadi tugas bersama antara masyarakat dan pemerintah. Sebab menurut peraturan pemerintah No.60 tahun 1999 bahwa tugas pemerintah didalam pelaksanaan pendidikan nasional adalah mengembangkan dan mengawasi terhadap praktik penyelenggarakan pendidikan. Dalam pelaksanaan tugas ini, peran pemerintah dapat dibantu oleh institusi-institusi baik yang difasilitasi oleh pemerintah maupun masyarakat, sehingga akan membangun jalinan yang simbiolis mutualistik di dalam kerangka mengembangkan sumber daya manusia (SDM) yang handal, beriman dan bertaqwa serta berkemampuan untyk menjadi agen perubahan sosial, sesuai dengan tuntutan pembangunan untuk mencapai kehidupan yang sejahtera. ${ }^{4}$

Pendidikan juga harus menyesuaikan dengan era globalisasi. Dan Ilmu pengetahuan dan teknologi (IPTEK) juga merupakan elemen penting dalam ajaran Islam untuk mengembangkan kesejahteraan manusia dan peradaban dunia. Pengalihan

\footnotetext{
${ }^{3}$ Prof. Dr. H. Said Husin AIMunawar, M.A Aktualisasi Nilai-Nilai Qurani Ciputat PT. Ciputat Press 2005 hal 12

${ }^{4}$ Ibid 39 
dan penghayatan ajaran Al-Quran dan al-hadith tentang iptek diharapkan semakin memperluas dan memperkokoh kerangka filosofi dan etik iptek, serta semakin mendorong tumbuhnya prakarsa keilmuan umat Islam abad XXI.

Kajian mengenai pendidikan masih saja merupakan hal menarik dianalisis dan dirumuskan keberadaannya. Dalam dunia termasuk Indonesia, pendidikan merupakan salah satu pilar pembangunan. Ini menandakan bahwa pendidikan tidak hanya berbicara pada konteks bagaimana pendidikan mampu memperbaiki struktur pembangunan dalam negara tersebut. Pada sisi ini pendidikan berfungsi sebagai penopang tegaknya pembangunan melalui penciptaan sumber daya manusia (SDM) berkualitas. Untuk menuju tercapainya harapan diatas, ada banyak variable yang perlu diadakan perbaikan. Sebab, pendidikan Indonesia saat ini sedang dirudung banyak masalah. Di samping itu, kondisi kritis ekonomi yang melanda Indonesia, berimplikasi serius pada pendidikan.

Seiring globalisasi dunia yang semakin nyata, maka intesitas pemanfaatan iptek dalam rekayasa pembangunan nasional, cenderung tidak terelakkan peningkatannya dari waktu-waktu. Sebagai alasan, karena membangun bukan lagi sekedar untuk bertahan atau berkembang, melainkan sudah masuk kerangka bersaing dengan produk rekayasa iptek bangsa lain. Tanpa peningkatan kuantitas dan kualitas pemanfaatan iptek, bisa jadi pembangunan akan berakhir pada kekecewaan, dan bukan kesejahteraan, apalagi kebanggaan sebagai suatu bangsa. Namun, bila dilihat dari segi lain, bahwa pembangunan di negeri ini adalah oleh dan untuk manusia seutuhnya, yang berarti mencita-citakan keseimbangan aspek fisik materiil dalam persaingan harmonisnya dengan aspek mental spiritual, demi tercapainya kesejahteraan duniawi sebagai sarana untuk mencapai kebahagiaan ukhrawi.

\section{Tujuan Pendidikan Islam}

Pendidikan berasal dari kata "didik", lalu mendapat awalan me menjadi mendidik, artinya memelihara dan memberi latihan. Dalam memelihara dan memberi latihan diperlukan adanya ajaran, tuntunan, dan pimpinan mengenai akhlak dan kecerdasan pikiran. Selanjutnya pengertian "pendidikan” menurut Kamus besar bahasa 
Indonesia ialah proses pengubahan sikap dan tata laku seseorang atau kelompok orang dalam usaha mendewasakan manusia melalui upaya pengajaran dan pelatihan. ${ }^{5}$

Pendidikan dapat diartikan sebagai sebuah proses dengan metode-metode tertentu sehingga orang memperoleh pengetahuan, pemahaman, dan cara bertingkah laku yang sesuai kebutuhan. Sebagian orang memahami arti pendidikan sebagai pengajaran karena pendidikan pada umumnya selalu membutuhkan pengajaran. Sedangkan menurut Poerbakawaja dan Harapan (1981) pendidikan adalah usaha secara sengaja dari orang dewasa untuk dengan pengaruhnya meningkatkan si anak ke kedewasaan yang selalu diartikan mampu menimbulkan tangung jawab moril dari segala perbuatannya....orang dewasa itu adalah orang tua si anak atau orang tua yang atas dasar tugas dan kedudukannya mempunyai kewajiban untuk mendidik misalnya guru sekolah, pendeta atau kyai dalam lingkungan keagamaan, kepala-kepala asrama dan sebagainya. ${ }^{6}$.

Dalam UU No. 2 / 1989 tentang system pendidikan nasional (UUSPN) menegaskan bahwa pendidikan merupakan usaha sadar yang menyiapkan peserta didik melalui upaya bimbingan, pengajaran, dan pelatihan untuk kehidupan dimasa datang, dengan tetap berakar pada kebudayaan bangsa Indonesia berdasarkan Pancasila dan UUD $1945^{7}$. UUSPN menunjukkan bahwa pendidikan nasional mempunyai tujuan dasar, yaitu mencerdaskan kehidupan bangsa dan mengembangkan manusia Indonesia seutuhnya. Konsep manusia seutuhnya itu dijabarkan dengan karakteristik manusia Indonesia yang beriman dan bertakwa terhadap Tuhan Yang Maha Esa, berbudi luhur, kepribadian yang mantap dan mandiri, rasa bertanggung jawab kemasyakatan dan kebangsaan. Dalam GBHN 1993 dikemukakan bahwa Pendidikan nasiaonal bertujuan untuk meningkatkan kualitas manusia Indonesia, yaitu manusia yang beriman dan bertakwa, berbudi luhur, berkepribadian, mandiri, maju, tangguh, cerdas, kreatif, terampil, berdisiplin, beretos kerja, professional, bertanggungjawab, dan produktif.

Dari pengertian normatif tujuan pendidikan Nasional tersebut dapat disimpulkan bahwa ada tiga dimensi atau aspek pendidikan yang dibina dan dikembangkan oleh

\footnotetext{
${ }^{5}$ Muhibin syah Psikologi pendidikan PT REMAJA ROSDAKARYA Bandung 2001 hal 10

${ }^{6}$ Ibid hal 10

${ }^{7}$ UU no 21989 
pendidikan nasional, yaitu ;1) Dimensi spiritual atau imtaq (keimanan, ketakwaan, berbudi pekerti luhur) ; (2) Dimensi budaya (kepribadian yang mantap dan mandiri, tanggung jawab kemasyarakatan dan kemasyarakat dan kebangsaan); dan (3) Dimensi kecerdasan (cerdas, kreatif trampil, disiplin, etos kerja, professional, produktif). ${ }^{8}$

Di samping pengertian normative tujuan pendidikan nasional, sebagaimana dikemukakan di depan, maka pengertian manusia yang berkualitas secara jelas juga dinyatakan dalam GBHN 1993, yaitu mewujudkan bangsa yang maju dan mandiri serta sejahtera lahir dan batin sebagai landasan bagi tahapan pembangunan selanjutkan menuju masyarakat adil dan makmur berdasar Pancasila dan UUD 1945. Istilah maju, mandiri, sejahtera lahir dan batin juga diulang dan ditekankan pada rumusan sasaran PJP II. Salah satu ciri masyarakat yang sejahtera secara batiniah ialah apabila kehidupan warganya senantiasa diwarnai oleh keimanan dan ketaqwaan ini juga merupakan asas bagi diselenggarakannya pembangunan nasional, yaitu bahwa segala usaha dan kegiatan pembangunan dijiwai, digerakkan, serta dikendalikan keimanan dan ketaqwaan sebagai nilai luhur yang menjadi landasan spiritual, moral dan etik. ${ }^{9}$

Sumber daya yang berkualitas yang dihasilkan oleh dunia diharapkan dapat memenuhi empat kompetensi, yaitu ; pertama, kompetensi akademik yaitu kompetensi yang berkaitan dengan kiat dan kemampuan metodologis keilmuan dalam rangka penguasaan dan pengembangan ilmu dan teknologi. Kompetensi akademik ini amat penting artinya bagi pengembangan iptek dan dihasilkan pemikiran, konsep, dan progam progam pembangunan yang inovatif. Kedua, kompetesni professional yaitu berkaitan dengan wawasan, perilaku, dan kemampuan penerapan ilmu dan teknologi dalam realitas kehidupan masyarakat. Kompetensi professional inilah yang menghadirkan manusia pembangunan yang handal. Ketiga, kompetensi nilai dan sikap. Kompetensi ini berkaitan dengan kemampuan untuk selalu menempatkan segala persoalan dalam kerangka nilai-nilai pancasila, budaya bangsa, serta iman dan taqwa kepada Tuhan yang maha Esa. Kompetensi ini merupakan bingkai dari kompetensi sebelumnya, sehingga menjadi lebih bermakna baik dalam konteks kepentingan bangsa dalam konteks pengabdian kepada Tuhan Yang Maha Kuasa. Keempat,

\footnotetext{
${ }^{8}$ Ibid hal 64

${ }^{99}$ Ibid hal 65 
Kompetensi untuk menghadapi perubahan meliputi tiga hal, yaitu ;

1. Kemampuan untuk memahami makna dan hakikat perubahan yang terjadi,

2. Kemampuan untuk mengantisipasi arah dan kecenderungan perubahan,

3. Kemampuan mengelola dan memanfaatkan, perubahan tersebut untuk mencapai keunggulan di masa depan.

Mereka dituntut untuk lebih mengembangkan wawasan yang berorientasi ke depan secara lebih utuh, yang bukan hanya bersifat jangka pendek. ${ }^{10}$ Dengan mempertimbangkan keempat kompetensi tersebut, maka strategi pendidikan terutama diarahkan pada upaya peningkatan mutu disegala bidang dan peningkatan relevansinya dengan kebutuhan pembangunan nasional, baik menyangkut kebutuhan dunia kerja dan industri akan tenaga kerja, pengembangan industri sesuai dengan perkembangan iptek, maupun menyangkut tantangan pembangunan masa depan.

Pengembangan sumber daya manusia dalam rangka mempersiapkan tenaga, pembangunan perlu direncanakan dengan cermat mengingat tiga hal, yaitu : pertama, proses pendidikan itu memerlukan waktu tenggang yang cukup lama. Setidak tidaknya seeorang dituntut untuk mengikuti proses pendidikan sejak tingkat sekolah dasar sampai perguruan tinggi selama 17 tahun lamanya. Kedua, dasar proses pendidikan juga, berlaku prinsip 'tak berubah'. Ketiga, tantangan yang kita hadapi di masa depan cenderung berkembang semakin kompleks yang ditandai semakin cepatnya perkembangan iptek sebagai akibat dari arus penduniaan yang semakin terbuka. ${ }^{11}$

Sebagian orang memahami arti pendidikan sebagai pengajaran karena pendidikan pada umumnya selalu membutuhkan pengajaran. Jika pengertian seperti itu kita pedomani, setiap orang yang berkewajiban mendidik (seperti guru dan orang tua) tentu harus melakukan perbuatan mengajar. Padahal, mengajar pada umumnya diartikan secara sempit dan formal sebagai kegiatan menyampaikan materi pelajaran kepada siswa agar menerima dan menguasai materi pelajaran tersebut, atau dengan kata lain agar siswa tersebut memiliki ilmu pengetahuan. ${ }^{12}$

\footnotetext{
${ }^{10}$ Ibid hal 66

11 Ibid hal 67

12 Ibid hal 11
} 
Pengembangan pendidikan Islam pun demikian, landasan idiil dari pendidikan Islam adalah perintah Allah tentang wajibnya mencari ilmu sehingga semua muslim berdosa jika tidak melaksanakannya. Kewajiban menuntut ilmu mengisyaratkan bahwa Allah dan Rasulullah SAW, tidak menghendaki umatnya menjadi umat yang bodoh dan terjebak dalam kemiskinan. Islam menghendaki umatnya menjadi umat yang intelek, cerdas, dan bermartabat. Semua tergantung pada pendidikan sebagai alat untuk mempertajam cara kerja otak manusia. Akan tetapi, kecerdasan umat Islam wajib diperkuat oleh kecerdasan emosional dan kecerdasan spiritualnya sehingga ilmu pengetahuan tidak digunakan untuk membinasakan sesama manusia ${ }^{13}$. Ahmad Tafsir mendefinisikan ilmu pendidikan Islam sebagai ilmu pendidikan yang berdasarkan Islam, dengan demikian ilmu pendidikan Islam adalah ilmu yang berdasarkan pada AlQuran, As-Sunnah dan akal. ${ }^{14}$

Dalam ilmu pendidikan Islam yang sumbernya wahyu Al-Quran, kajiannya tidak sebatas yang berkaitan dengan sains, filsafat, dan agama dalam arti doktrin. Karena didalam Al-Quran dibicarakan persoalan hukum alam, hukum Allah, hukumhukum kemanusiaan dan masalah-masalah yang metafisikal, semua menjadi objek kajian ilmu pendidikan Islam. Dengan demikian sepantasnyalah mempelajari semua hal berkaitan dengan masalah tersebut, bukan hanya masalah yang menyangkut pendidikan dalam arti keguruan dan pengajaran. ${ }^{15}$

Nilai-nilai Islam itulah yang ditumbuh kembangkan dalam diri pribadi manusia melalui proses tranformasi kependidikan. Proses kependidikan yang mentranformasikan (mengubah) nilai tersebut selalu berorientasi pada kekuasaan Allah dan Iradah-Nya yang menentukan keberhasilannya. Kemajuan peradaban manusia melingkupi kehidupannya bagi manusia yang berkepribadian Islam, hasil proses kependidikan Islam akan tetap merasa berada dalam lingkaran hubungan vertical dengan TuhanNya, dan hubungan horizontal dengan masyarakat. ${ }^{16}$

\footnotetext{
${ }^{13}$ Drs hasan Basri, MAg Drs Beni Ahmad Saebeni, M.Si ILMU PENDIDIKAN ISLAM (JILID II) CV PUSTAKA SETIA 2010 hal 21

${ }^{14}$ Ahmad tafsir Ilmu Pendidikan Islam Bandung Pustaka Setia 1999

15 Beni Ahmad Saeebeni dan Hendra Akhdhiyat Ilmu Pendidikan Islam I Insan Mandiri 2007 hal $123-124$

16 H. Mujayin arifin, Pendidikan Islam dalam Arus Dinamika Masa. Golden Terayon, 1987 hal : 4 
Usaha untuk merinci tujuan pendidikan Islam sudah pernah dilakukan oleh para ahli pendidikan Islam. Al-Syaibani misalnya, menjabarkan tujuan pendidikan Islam menjadi $;^{17}$

1. Tujuan yang berkaitan dengan individu, mencakup perubahan yang berupa pengetahuan, tingkah laku, jasmani dan rohani, kemampuan-kemampuan yang harus dimiliki untuk hidup di dunia dan di akhirat.

2. Tujuan yang berkaitan dengan masyarakat, mencakup tingkah laku masyarakat, tingkah laku individu dalam masyarakat, perubahan kehidupan masyarakat, memperkaya pengalaman masyarakat.

3. Tujuan profesioanal yang berkaitan dengan pendidikan dan pengajaran sebagai ilmu, sebagai seni, sebagai profesi, dan sebagai kegiatan masyarakat.

Al-Abrasyi merinci tujuan akhir pendidikan Islam menjadi ;

1. Pembinaan Akhlak;

2. Menyiapkan anak didik untuk hidup dunia akhirat;

3. Penguasaan ilmu;

4. Ketrampilan bekerja dalam masyarakat.

Asma Hasan Fahmi merinci tujuan akhir pendidikan Islam ;

1. Tujuan keagamaan;

2. Tujuan pengembangan akal dan akhlak;

3. Tujuan pengajaran kebutuhuan pembinaan kepribadian.

Munir Mursi menjabarkan tujuan pendidikan Islam menjadi sebagai berikut ;

1. Bahagia di dunia dan di akhirat ;

2. Menghambakan diri kepada Allah;

3. Memperkuat ikatan keislaman dan melayani kepentingan msyarakat Islam;

4. Akhlak mulia.

\section{Manusia Sempurna dan Unggul Menurut Islam}

\footnotetext{
${ }^{17}$ Dr. Ahmad Tafsir IImu Pendidikan Dalam Prespektif Islam PT REMAJA ROSDAKARYA, Jakarta 2007 hal 49
} 
Ciri manusia unggul sempurna menurut Islam yang diharapkan mampu menjalani kehidupan dengan beragama dan mampu menghadapi perubahan zaman. Manusia Sempurna dan Unggul menurut Islam tidak mungkin di luar hakikatnya. Berikut ini diuraikan ciri manusia sempurna unggul menurut Islam.

1. Jasmani Yang Sehat serta Kuat dan Berketrampilan ${ }^{18}$

Orang Islam perlu memiliki jasmani yang sehat serta kuat, terutama berhubungan dengan keperluan penyiaran dan pembelaan serta penegakan ajaran Islam. Di lihat dari sudut ini maka Islam mengidealkan Muslim yang sehat serta kuat jasmaninya.

Dalam penegakan ajaran Islam, terutama pada masa penyiarannya dalam sejarah, tidak jarang ditemukan rintangan yang pada akhirnya memerlukan kekuatan dan kesehatan fisik (jasmani). Kadang-kadang kekuatan dan kesehatan itu diperlukan untuk berperang menegakkan ajaran Islam. Ternyata sampai sekarang pun tantangan fisik seperti dalam sejarah tersebut sering juga muncul. Oleh karena itu, sekarang pun Muslim harus sehat dan kuat fisiknya.

Islam mengkendaki agar orang Islam itu sehat mentalnya karena inti ajaran Islam (iman) adalah persoalan mental. Kesehatan mental berkaitan erat dengan kesehatan jasmani. Karena kesehatan mental penting, maka kesehatan jasmani pun penting pula. Karena kesehatan jasmani itu sering berkaitan dengan pembelaan Islam, maka sejak permulaan sejarahnya pendidikan jasmani (orang sehat dan kuat) diberikan oleh para pemimpin Islam. Pendidikan itu langsung dihubungkan dengan pembelaan Islam, yaitu berupa latihan memanah, berenang, menggunakan senjata, meunggang kuda, lari cepat. Pentingnya kekuatan dan kesehatan fisik itu juga mempunyai dalil-dalil naqli.

Dalam surat al-Anfal ayat 60 disebutkan agar orang Islam mempersiapkan kekuatan dan pasukan berkuda untuk menghadapi musuh-musuh Allah. Yang dimaksud dengan musuh Allah ialah yang mengancam agama Islam. Persiapan itu diselenggarakan antara lain berupa pendidikan jasmani. Ada

${ }^{18}$ Ibid ; hal 41 
beberapa sabda Rosulullah saw. yang menerangkan perlunya ketrampilan memanah dimiliki oleh orang Islam. Menunggang hewan, antara lain kuda, juga dipentingkan Umar bin Khattab memerintahkan gubernur-gubernurnya agar melatih anak-anak mereka berenang dan menunggang kuda. Imam Al-Shazali, juga menekankan perlunya pendidikan jasmani. Secara umum, Islam lebih menyenangkani Muslim yang kuat daripada Muslim yang lemah, juga dalam pengertian kuat jasmani.

Jasmani yang berkembang dengan baik haruslah kuat, artinya orang itu harus kuat secara fisik. Cirinya yang mudah dilihat ialah adanya otot yang berkembang dengan sempurna. Hasil yang diperoleh ialah kemampuan beradaptasi yang tinggi, kemampuan pulih (recover) yang cepat, dan kemampuan beradaptasi yang tinggi, kemampuan menahan letih, yaitu tidak cepat letih. Tanda yang lain ialah aktif, berpenampilan segar. Jasmani yang sehat serta kuat itu akan menampilkan tubuh yang indah ; keindahan adalah salah satu aspek kehidupan yang dipentingkan di dalam Islam.

Kesehatan dan kekuatan juga berkaitan dengan kemampuan menguasai filsafat dan sains serta pengelolaan alam. Oleh karena itu, semakin wajarlah kiranya bila Islam memandang jasmani yang sehat serta kuat sebagai salah satu ciri muslim yamg sempurna. Pada jasmani yang demikian itu terdapatlah indera yang sehat dan bekerja dengan baik. Indera yang baik diperlukan dalam penguasaan filsafat dan sains, serta dalam pengelolaan alam. Kesimpulannya adalah wajar bila Islam memandang jasmani yang sehat dan kuat sebagai salah satu ciri muslim yang ideal.

Jasmani yang sehat serta kuat berkaitan juga dengan ciri lain yang dikehendaki ada pada Muslim yang sempurna, yaitu menguasai salah satu ketrampilan yang diperlukan dalam mencari rezeki untuk kehidupan. Para pendidik Muslim sejak zaman permulaan perkembangan Islam telah mengetahui pentingnya pendidikan ketrampilan berupa pengetahuan praktis dan latihan kejujuran.

Sedangkan Muslim yang hidup pada zaman modern ini juga di Indonesia, tidaklah mungkin meremehkan pendidikan ketrampilan. Orang akan 
sulit sekali menyelenggrakan kehidupannya tanpa memiliki salah satu ketrampilan yang diperlukan dalam kehidupannya. Salah satu ciri muslim yang baik ialah memiliki sekurang-kurangnya satu jenis ketrampilan yang diperlukan dalam kehidupan.

2. Cerdas Serta Pandai ${ }^{19}$

Islam menginginkan pemeluknya cerdas serta pandai. Itulah ciri akal yang berkembang secara sempurna. Cerdas ditandai oleh adanya kemampuan menyelesaikan masalah dengan cepat dan tepat, sedangkan pandai ditandai oleh banyak memiliki pengetahuan, jadi banyak memiliki informasi. Salah satu ciri Muslim yang sempurna ialah cerdas serta pandai. Kecerdasan dan kepandaian itu dapat ditilik melalui indikator-indikator sebagai berikut ini.

Pertama, memiliki sains yamg banyak dan berkualitas tinggi. Sains adalah pengetahuan manusia yang merupakan produk indera dan akal ; dalam sains kelihatan tinggi atau rendah mutu akal. Orang Islam hendaknya tidak hanya menguasai teori-teori sains, tetapi berkemampuan pula menciptakan teori-teori baru dalam sains, termasuk teknologi. Kedua, mampu memahami dan menghasilkan filsafat. Berbeda dengan sains, filsafat adalah jenis pengetahuan yang semata-mata akliah. Dengan ini, orang Islam akan mampu memecahkan masalah filosofis.

Perlunya ciri akliah dimiliki oleh Muslim dapat diketahui dari ayat-ayat al-Quran serta hadis Nabi Muhammad Saw. ayat dan hadis itu biasanya diungkapkan dalam bentuk perintah agar belajar dan atau perintah menggunakan indera dan akal, atau pujian kepada mereka yang menggunakan indera dan akalnya. Nabi Muhammad menyatakan bahwa pengetahuan dapat diperoleh dengan cara belajar, dan umat Islam diperintahkan agar belajar. Surat al-Alaq ayat 1 mengandung pengertian bahwa orang Islam seharusnya dapat membaca. Ayat ini mengandung perintah agar umat Islam belajar karena pada umumnya kemampuan membaca itu diperoleh dari belajar. Dalam Al-Quran surat al-Nahl ayat 43 Tuhan menyuruh orang Islam bertanya jika ia tidak tahu. Ini dapat diartikan sebagai suruhan belajar.

${ }^{19}$ Ibid ; hal 43 
Jadi, jelaslah bahwa Islam menghendaki agar orang Islam berpengetahuan. Ini adalah salah satu akal yang berkembang baik. Akal yang berkembang baik itu berisi banyak pengetahuan sains, filsafat, serta mampu menyelesaikan masalah secara ilmiah dan atau filosofis.

Akal yang cerdas adalah karunia Tuhan. Indikatornya ialah kecerdasan umum (IQ). Kecerdasan itu, selalin ditentukan oleh Tuhan, juga berkaitan dengan keturunan. Kesehatan jiwa dan fisik jelas berkaitan pula dengan kecerdasan tersebut. Kalau begitu, kesehatan dan kekuatan seperti yang telah diuraiakan sebelum ini memang berkaitan juga dengan tingkat kecerdasan.

3. Rohani Yang Berkualitas Tinggi

Seperti telah diuraikan sebelum ini, rohani yang dimaksud di sini ialah aspek manusia selaian jasmani dan akal (logika). Rohani itu samar, ruwet, belum jelas batasannya; manusia belum (atau tidak akan) memiliki cukup pengetahuan untuk mengetahui hakikatnya. Kebanyakan buku tasawwuf dan pendidikan Islam menyebutkan qalbu(kalbu) saja.

Kalbu sekalipun tidak jelas hakikatnya, apalagi rinciannya gejalanya jelas. Gejalanya itu diwakilkan dalam istilah rasa. Rincian rasa tersebut misalnya sedih, rindu, sabar, serakah, putus asa, cinta, benci, iman, bahkan kemampuan melihat yang ghaib, termasuk "melihat" Tuhan, surga, neraka dan lain-lain. Kata "melihat" Tuhan dan sebagainya itu sebenarnya adalah "merasakan". Kemampuan memperoleh ilmu laduni atau ilmu kasyf dalah bagian dari kerja kalbu.

Kekuatan jasmani terbatas pada objek-objek berwujud materi yang dapat ditangkap oleh indera. Kekuatan akal atau pikir betul-betul sangat luas; dapat mengetahui objek yang abstrak, tetapi sebatas dapat dipikirkan secara logis. Kekuatan rohani (tegas kalbu) lebih jauh daripada kekuatan akal. Bahkan ia dapat mengetahui objek secara terbatas. Karena itu, Islam amat mengistimewakan aspek kalbu. Kalbu dapat menembus alam gaib, bahkan menembus Tuhan. Kalbu inilah yang merupakan potensi manusia yang mampu beriman secara sungguhsungguh. Bahkan iman itu, menurut al-Quran tempatnya di dalam kalbu. 
Iman itu bukan di kepala. Yang ada di kepala, yang ada di kepala ialah pengetahuan tentang iman, pengetahuan tentang Tuhan, tetapi yang di kepala itu iman, iman itu di dalam hati. Beradsarkan uraian ini jelaslah bahwa kalbu yang berkualitas tinggi itu adalah kalbu yang penuh berisi iman kepada Allah; atau dengan ungkapan lain, kalbu yang takwa kepada Allah. Kalbu yang penuh iman itu mempunyai gejala-gejala yang amat banyak; katakanlah rinciannya amat banyak. Kalbu yang iman itu ditandai bila orangnya salat, ia salat dengan khusyuk (al-Mu'min ; 1-2) bila mengingat Allah, kulit dan hatinya tenang (alZumar;23) bila disebut nama Allah, bergetar hatinya (al-Hajj;34-35) bila dibacakan kepada mereka ayat-ayat Allah, mereka sujud dan menangis (Maryam;58, al-Isra';109) . Itulah ciri utama hati yang penuh iman atau takwa. Dari situlah akan muncul manusia yang berfikir dan bertindak sesuai dengan kehendak Tuhan. Jadi, dapatlah disimpulkan bahwa manusia sempurna dalam pandangan Islam ialah manusia yang hatinya penuh iman dan takwa kepada Tuhan.

Seluruh uraian tentang ciri manusia sempurna dan unggul menurut Islam ini dapat diringkaskan sebagai berikut. Manusia sempurna dan unggul menurut Islam haruslah ;

1. Jasmani sehat serta kuat, termasuk berketrampila

2. Akalnya cerdas serta pandai

3. Hatinya (kalbunya) penuh iman kepada Allah

\section{Simpulan}

Konferensi Dunia pertama tentang pendidikan Islam (1977) berkesimpulan bahwa tujuan akhir pendidikan Islam adalah manusia yang menyerahkan diri secara mutlak kepada Allah. Bisa di sini dapat dilihat bahwa para ahli pendidikan Islam sepakat bahwa tujuan pendidikan Islam ialah manusia yang baik itu ialah manusia yang beribadah kepada Allah ; manusia yang baik itu adalah yang takwa kepada Allah. Aspek ibadah yang pertama ialah apa yang diperoleh oleh fuqaha disebut ibadat, yaitu rukun Islam seperti yang disebut di dalam hadist yang diriwayatkan baik oleh Bukhari maupun oleh 
Muslim, yang berisi rukun Islam yang lima itu. Aspek ibadah yang ini merupakan kewajiban orang Islam untuk mempelajarinya agar ia dapat mengamalkan dengan cara yang benar. Pengetahuan tentang Al-quran dan Hadist, terutama tentang kelima rukun Islam, jelas harus menjadi salah satu tujuan pendidikan Islam.

Berdasarkan ijtihad para ahli membagi aspek-aspek pembinaan dalam pendidikan Islam sebagai berikut ;

1. Aspek jasmani

2. Aspek akidah

3. Aspek akhlak

4. Aspek kejiwaan

5. Aspek keindahan

6. Aspek kebudayaan

Sedangkan ciri Muslim sempurna dan unggul menurut Islam adalah ;

1. Jasmaninya sehat dan kuat, dengan cirinya adalah ;
a. Sehat
b. Kuat
c. berketrampilan

2. Akalnya cerdas serta pandai; dengan cirinya adalah ;
a. Mampu menyelesaikan masalah secara cepat dan tepat
b. Mampu menyelesaikan masalah secara ilmiah dan filosofis
c. Memiliki dan mengembangkan sains
d. Memiliki dan mengembangkan filsafat

3. Hatinya takwa kepada Allah berciri-ciri ;
a. Dengan sukarela melaksanakan perintah Allah da menjauhi laranganNya
b. Hati yang berkemampuan berhubungan dengan alam ghaib/ iman

Dari penjabaran diatas maka bisa diambil kesimpulan bahwa tujuan pendidikan Islam ialah Muslim yang sempurna, atau manusia yang takwa, beriman dan manusia yang beribadah kepada Allah serta memiliki ciri sebagai muslim yang sempurna dan unggul menurut Islam. sehingga dengan menerapkan pendidikan Islam yang tepat mampu mencetak sumber daya manusia unggul yang bermanfaat dan kompeten di zaman modern sesuai perkembangan zaman. 


\section{Daftar Pustaka}

Sholahuddin Mahfud, Metode Pendidikan Islam, Surabaya, Bina Ilmu 1987

Basri Hasan, Ahmad Saebeni, Ilmu Pendidikan Islam (jilid ii) CV PUSTAKA SETIA2010

Husin AlMunawar Said, Aktualisasi Nilai-Nilai Qurani Ciputat PT. Ciputat Press 2005

Rusman, Model-Model Pembelajaran, Jakarta, PT Rajajagrafindo Persada 2012

Syah Muhibin Psikologi Pendidikan PT REMAJA ROSDAKARYA Bandung 2001

UU no 21989

Tafsir Ahmad Ilmu Pendidikan Islam, Bandung Pustaka Setia 1999

Saeebeni Beni Ahmad dan Hendra Akhdhiyat Hendra, Ilmu Pendidikan Islam I Insan Mandiri 2007

Arifin Mujayin , Pendidikan Islam dalam Arus Dinamika Masa. Golden Terayon, 1987. Tafsir Ahmad Ilmu Pendidikan Dalam Prespektif Islam PT REMAJA ROSDAKARYA, Jakarta 2007 